\title{
A Comparative Study of the Impact of Metalinguistic Feedback and Explicit Correction on the Writing Performance of Iranian EFL Learners
}

\author{
Yazdan Azizi Khah \\ Department of ELT, College of Literature and Humanities, Kermanshah Branch \\ Islamic Azad University, Kermanshah, Iran \\ E-mail: yazdan.azizi100@gmail.com \\ Majid Farahian \\ Department of ELT, College of Literature and Humanities, Kermanshah Branch \\ Islamic Azad University, Kermanshah, Iran \\ E-mail: farahian@iauksh.ac.ir
}

Received: March 13, 2016 Accepted: April 28, 2016 Published: May 1, 2016

doi:10.5296/jse.v6i2.9082 URL: http://dx.doi.org/10.5296/jse.v6i2.9082

\begin{abstract}
The present study aimed at investigating the impact of two different strategies of providing written corrective feedback on English as foreign language (EFL) learners' writing performance. To achieve this goal, sixty EFL learners who participated in the study were assigned into two groups. Throughout the period of the study, two techniques of written feedback, metalinguistic feedback and explicit correction feedback were put into practice as the treatment. The first writing assignment was used as the pretest and the last writing assignment was the posttest. To determine the proficiency level of the participants, A Nelson English Proficiency Test was used. The result of the paired t-tests showed that the writing performance of two groups improved; however, the independent t-test was performed between the posttests of the two groups indicated that the group with metalinguistic feedback had greater improvement than the group which received the explicit correction feedback. The findings suggest that providing teacher corrective feedback is effective in reducing EFL learners' grammatical errors and improves their writing achievement.
\end{abstract}


Keywords: Explicit correction, Feedback, Language Proficiency, Metalinguistic feedback, Writing skill 


\section{Introduction}

Writing skill is human's valuable and useful inheritance. It makes it possible for people to communicate with each other across countries and nations. It also enables them to leave record their dairies and accomplishments for future generations. Writing has always been considered a fundamental skill in education and is a skill which has various benefits for the learners in all educational settings. Success in education depends, to a great extent to the mastery of this skill; however, a lot of students have problem mastering writing skill.

EFL learners, as other learners, need to gain mastery of EFL writing; however, in the process of writing they make errors which need to be taken care of. The way EFL teachers correct EFL learners' writing may have a great impact on the learners' writing achievement and their inclination to compose.

Various techniques of error correction have been researched by scholars and different recommendations have been proposed regarding how to deal with EFL learners' errors; nonetheless, as it has been argued, there is no corrective feedback procedure for all learners and teachers must not generalize one specific technique to all learners (Ellis (2009). Moreover, EFL teachers can apply different feedbacks as different techniques might appeal to different learners for their needs, proficiency level, and classroom objectives.

Feedback has three advantages: first, EFL learners can make sure whether they are performing well or not (Littleton, 2011). Second, as Getchell (cited in Elashri, 2013) states, feedback helps learner to take corrective action about their writing in order to improve it. Third, feedback helps students monitor their progress (Asiri, 1996). According to Hino (2006) another valuable feature about feedback is that it is a good indication of how EFL learners are progressing in learning the written skill and so assists the teachers in assessing their students' problem. Butler (1988) argues that self confidence in writing and motivation that feedback gives students is an important feature of feedback in the concept of active learning. Goldstein (2004) states that the good constructive feedback also causes learners to better revise drafts which at last increase their self-confidence in their writing skill. It also cause increases more self-regulated learning which occurs when students receive good feedback on a draft from the lecturer in class and are required to revise based on the written feedback provided.

As the matter of fact recently the ways instructors correct FL learners' writing texts is a matter that has attracted enormous interest among instructors and researchers. However, a recent review by Hyland (cited in Corpuz, 2011), about feedback on students' writing skill indicates that despite all study and research, there are still no precise answers to the questions researchers have addressed.

In contrast to those views which are in favor of error correction, Truscott (1999) has a strong view against error correction. He explained that all forms of error correction and feedback are ineffective and also harmful and should be ignore and abandoned. Ferris (1999) rejects such a view and states that it is not possible to dismiss error correction in general as correction has a 


\section{Macrothink}

key role in acquisition. Numbers of recent studies (e.g. Ellis, 2008 \& Sheen, 2007) have produced some evidence to state that written $\mathrm{CF}$ can result in acquisition.

All in all, due to perplexing findings the researchers sought to answer the following questions:

1) Does explicit correction feedback have a significant effect on EFL learners' writing proficiency?

2) Does metalinguistic feedback have a significant effect on EFL learners' writing proficiency?

3) Does exposure to metalinguistic feedback in EFL learners' writing lead to a greater improvement than exposure to explicit correction feedback?

\section{Method}

\subsection{Design}

The present research was a quasi-experimental study having one independent variable and one dependent variable.

\subsection{Participants}

The participants were 60 EFL learners (36 females, 24 males) studying English at four English language teaching institutes in Kermanshah, a city in west of Iran. All the participants were high school or pre university students. They were all Persian native speakers aged between 14 to 20. They were selected out of 93 EFL learners who took the Nelson test.

Participants were randomly divided into two groups, each group consisted of 30 learners and one group received metalinguistic feedback and the other group received explicit correction feedback. Members of both groups consisted of both male and female participants. Two raters also participated in the study in order to enhance the inter rater reliability of the scoring procedure.

\subsection{Procedure}

To select the participants of this study, at the beginning of the course, first, a 50-item Nelson English Language Proficiency Test was administered to a sample of 93 students. The purpose of this test was to make sure that there were no substantial differences among the learners with respect to their proficiency level. Then, the mean and standard deviation of the participants' scores on the proficiency test were computed; which turned out to be 25 and 9, respectively.

To ensure the homogeneity of the participants, those who had scored more than one standard deviation away from the mean were removed from all participants, and 60 learners, from among 93 ones, whose scores were from 16 to 34, were selected. 


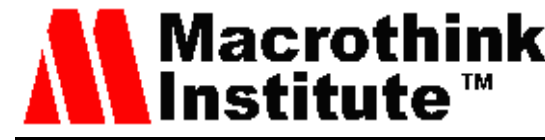

The reason why a general proficiency test, rather than a writing pretest, was used to homogenize the participants was that if the participants' homogeneity was determined only on the basis of their pretest writing, there might be the danger of some generally more proficient learners accidentally lacking the background or motivation to write on a specific topic, thus performing worse than other generally less proficient learners. To avoid this problem, Nelson English Language Proficiency Test was employed. At the same time, the mean score of pretest of the learners confirmed their homogeneity.

Then students were randomly assigned to two experimental groups, one receiving explicit correction feedback and the other one receiving metalinguistic feedback. Each group included 30 students. The participants were not attending any other English class during the treatment period. The course ran for 10 sessions.

In each session, as part of the homework, a common topic was introduced and students were required to write about three or four paragraphs optional on it and submit it to the teacher the following session. The teacher did not score the writings as the final product. He, rather, provided different forms of corrective feedback on the students' writings depending on the group that students were attending and returned them to the students the following session.

One group received explicit correction that instructor provided clearly the correct form of errors to students' writings. The second experimental group members were provided metalinguistic feedback including information and guidance related to well-formed of learners' errors, without explicitly providing the correct form for learners. So, the learners reviewed their writing along with the provided feedback and then applied the feedback in their next writing in next session.

The first writing was considered as the pretest and in the last writing task was the post test. Then the data was collected, and in order to enhance inter rater reliability, two raters scored the papers in the present study. Then the raw scores were analyzed through SPSS software.

Example of metalinguistic feedback:

Learner: *He watch TV yesterday.

Teacher: watch. You should use the past tense.

\subsection{Instrument}

The first instrument was a Nelson English Language Test (Coe \& Fowler, 1976). The Nelson English Language Test is a battery consisting of 40 separate tests for ten levels of language proficiency ranging from beginners to the advanced. The levels are numbered from 050, 100, $150 \ldots$ to 500 . Each test consists of 50 items.

The pre-post measurement sessions of writing tasks aimed at assessing students' progress in writing accuracy across time. In both pre-post measurement sessions, the students were required to write three or four paragraphs on the assigned topics and their scores ranged from 0 to 20 depending on the number of errors. The reliability of both measurement sessions was 
approved through intra-rater reliability, and the topic and content of the tasks were consulted with two university instructors.

\section{Results}

\subsection{The Descriptive Statistic for Proficiency Test (Nelson)}

After collecting the data using Nelson English Language Proficiency Test, as Table 1 shows, base on the mean score $(M=25)$ and standard deviations ( $\mathrm{SD}=9)$ assessed by SPSS 19, 60 participants from among 93 ones whose scores were from 16 to 34 were selected.

Table 1. The Mean Score and Standard Deviation of the Nelson Test

\begin{tabular}{lccccc}
\hline & N & Min & Max & Mean & SD \\
\hline Scores & 93 & 7.00 & 45.00 & 25.10 & 9.10 \\
\hline
\end{tabular}

\subsection{The Analysis of Inter Rater Reliability}

The inter rater reliability of the scoring procedure was estimated prior to the statistical analysis. The index of Inter- Rater Reliability (Cronbach alpha) was .91 showing a high level of agreement between two different raters in the present study.

\subsection{The Analysis of Data}

By comparing the mean scores of the groups in the pretest the homogeneity of participants was calculated. As Table 2 shows, the mean score of the groups were about the same and this indicated that the participants in both groups were consistent in terms of their homogeneity.

Table 2. Mean Score of the Students of both Groups in the Pretest

\begin{tabular}{lllcc}
\hline & & $\mathrm{N}$ & Mean & Std. Deviation \\
\hline Pretest & Explicit correction & 30 & 12.33 & 2.14 \\
& Metalinguistic & 30 & 12.20 & 2.11 \\
\hline
\end{tabular}

The data collected from the pretest and the posttest in both groups were analyzed to see whether there was any gain score in each group as a result of the specific type of feedback. This was carried out by comparing the mean score of the students in each group from pretest to posttest. To this end, a paired-sampled t-test was used for each group separately.

\subsubsection{Addressing the First Research Question}

In a bid to address the first research question "Does explicit correction feedback have a significant effect on EFL learners' writing proficiency?", a paired t-test was conducted to compare the mean scores of the participants on the pretest and posttest of the explicit correction feedback group in order to investigate the effect of explicit correction feedback on the improvement of the writing proficiency of explicit correction feedback group. Tables 3 and 4 show the result of the comparison between the pretest and the posttest in a group which received the explicit instruction. 
Table 3. Pretest-posttest Comparative Data for Explicit Correction Feedback Group

\begin{tabular}{cccc}
\hline & $\mathrm{N}$ & Mean & Std. Deviation \\
\hline Pretest & 30 & 12.33 & 2.14 \\
Posttest & 30 & 14.03 & 1.37 \\
\hline
\end{tabular}

Table 4. Paired Sample Test for Explicit Correction Feedback Group

\begin{tabular}{lccccc}
\hline & \multicolumn{5}{c}{ Paired Differences } \\
\cline { 2 - 6 } & Mean & Std. Deviation & $\mathrm{t}$ & $\mathrm{df}$ & Sig. (2-tailed) \\
\hline Pretest- posttest & -1.70 & 1.73 & -5.36 & 29 & .000 \\
\hline
\end{tabular}

In Table 3, it is shown that the mean scores for the pretest and posttest of explicit correction feedback group were 12.33 and 14.03, respectively. As it can be seen in Table 4, the probability of $t(-5.36)$ has the $p<.001$ that is lower than the significance level of .05 . Therefore, it could be concluded that the mean scores of the pretest and posttest were significantly different. Consequently, our hypothesis that "explicit correction feedback doesn't have any significant effect on EFL learners' writing proficiency" was rejected.

\subsubsection{Addressing the Second Research Question}

To address the second research question "Does metalinguistic feedback have a significant effect on EFL learners' writing proficiency?", a paired t-test was conducted to compare the mean scores of the participants on the pretest and posttest of the metalinguistic feedback group in order to investigate the effect of metalinguistic feedback on the improvement of the writing proficiency of metalinguistic feedback group. Tables 5 and 6 show the result of the comparison between the pretest and the posttest in a group which received metalinguistic feedback.

Table 5. Pretest-posttest Comparative Data for Metalinguistic feedback Group

\begin{tabular}{cccc}
\hline & $\mathrm{N}$ & Mean & Std. Deviation \\
\hline Pretest & 30 & 12.20 & 2.11 \\
posttest & 30 & 15.06 & 1.15 \\
\hline
\end{tabular}

Table 6. Paired Sample Test for Metalinguistic feedback Group

\begin{tabular}{lccccc}
\hline & \multicolumn{5}{c}{ Paired Differences } \\
\cline { 2 - 6 } & Mean & Std. Deviation & t & df & Sig. (2-tailed) \\
\hline Pretest- posttest & -2.86 & 2.02 & -7.76 & 29 & .000 \\
\hline
\end{tabular}

As Table 5 illustrates, the mean scores for the pretest and posttest of metalinguistic feedback group were 12.20 and 15.06, respectively. Based on Table 6 , the probability of $t(-7.76)$ had the $\mathrm{p}<.001$ that is lower than the significance level of .05 . Therefore, it could be concluded that the mean scores of the pretest and posttest were significantly different. Consequently, our 
hypothesis that "metalinguistic feedback doesn't have any significant effect on EFL learners' writing proficiency." was rejected.

\subsubsection{Investigation of the Third Research Question}

In order to answer the third research question "Does exposure to metalinguistic feedback in EFL learners' writing lead to a greater improvement than exposure to explicit correction feedback?", an independent samples t-test was also run to compare the mean scores of posttest of writing in both groups in order to investigate the achievement of metalinguistic feedback with explicit correction feedback in the participants' writing proficiency.

It is shown in Table 7 that the mean scores for the posttest of explicit correction feedback and metalinguistic feedback groups were 14.03 and 15.06, respectively, so the metalinguistic feedback group outperformed the explicit correction feedback group in posttest of writing. Table 8 shows the results of the independent t-test of the posttests of writing for metalinguistic feedback and explicit correction feedback groups.

Table 7. The Comparative Data on Posttests in Both Groups

\begin{tabular}{cccc}
\hline & $\mathrm{N}$ & Mean & Std. Deviation \\
\hline explicit & 30 & 14.03 & 1.37 \\
metalinguistic & 30 & 15.06 & 1.15 \\
\hline
\end{tabular}

Table 8. Independent Samples T-Test for Both Groups

\begin{tabular}{lccccc}
\hline & \multicolumn{2}{l}{$\begin{array}{l}\text { Levine's Test for } \\
\text { Equality of Variance }\end{array}$} & \multicolumn{2}{c}{ t-test for Equality of Means } \\
\cline { 2 - 6 } & $\mathrm{F}$ & $\mathrm{Sig}$ & $\mathrm{t}$ & $\mathrm{df}$ & Sig. (2-tailed) \\
\hline posttests & .468 & .497 & -3.15 & 58 & .003 \\
\hline
\end{tabular}

As it can be seen, the probability of $t(-3.15)$ had the $p<.001$ that is lower than the significance level of .05 . Therefore, it could be concluded that there was a significant difference between the mean scores of posttest for the two groups. And we saw these groups in pretests were approximately the same. Consequently, our assumption that "exposure to metalinguistic feedback is not significantly difference from exposure to explicit correction feedback" was rejected. Thus, the metalinguistic feedback group performed better and achieved more regarding the treatment and feedback.

\section{Discussion}

In general, results of the current study provide clear evidence in support of teacher corrective feedback as advocated by some previous researchers such as Bitchener (2008), Chandler (2003), and Ellis (2008), Ferris (1999). Also the findings indicated that feedback is beneficial for learning, regardless of the feedback strategies. The findings also provide additional evidence in support of teacher feedback against the claim of Truscott who sparked the debate 
about the effectiveness of corrective feedback. Truscott $(1996,1999)$ explained that corrective feedback is ineffective in improving student writing and also it is significantly harmful. Therefore, he states that grammar correction feedback should be avoided.

Additionally, Hsu and Truscott (2008) concluded that reduction of error during revision by learner cannot be considered as a predictor of learning process and also improvements of treatment groups on the post-test cannot be considered as evidence on the effectiveness of corrective feedback on students' writing ability.

As the findings of this study showed, in contrast to Hsu and Truscott (2008) who found that successful error reduction of students is not related to learning, there was empirical evidence in result of this study that teacher written corrective feedback was effective in reducing EFL learners' errors. The results of this study clearly shows that learners learned effectively from teacher corrective feedback by using correct form of some previous their errors in writing the new essay each session. Thus, EFL learners reduced their grammatical errors in their new writings. The findings and results of this study may provide clear empirical evidence that the reduction of errors in learners' writings was in fact a result of learning from corrective feedbacks that they received during the treatment period and they applied in their writings.

Regarding the first and second research question, it was found that the metalinguistic feedback and explicit correction feedback had a positive influence on the writing improvement of the Iranian EFL students. These results are consistent with those of the other research, in their studies, some researchers (Bitchener, 2008; Ellis, 2008; Lyster, 2007; Sheen, 2007) explained that all treatment groups that received teacher written corrective feedback outperformed non-feedback control groups; it means that written corrective feedback is positive.

As to the third research question, it was found that exposure to metalinguistic feedback in EFL learners' writing lead to greater effect than exposure to explicit correction feedback. There are some reasons why the provision of metalinguistic feedback performed in this study resulted in writing improvement. One possible reason of this claim can be because of increasing awareness of the language rules and noticing of learners as an essential part of language learning (Schmidt, 1993). It gives students information about the errors they made, so that they are prompted to think about the structures they used and consequently take responsibility and react to feedback for their own learning during writing or task. The second reason is that the metalinguistic feedback usually includes information on parts of speech like preposition, verb, and relative pronoun for the intention of explaining a speech episode. Schmidt's (2001) noticing hypothesis which confirms the importance role of attracting the students' attention to formal features of language for achieving linguistic development and metalinguistic feedback is a good strategy of making students to overtly identify the gap or mismatch between their interlanguage and the target forms (errors). 


\section{Conclusion}

Based on the results of this study it seems that written corrective feedback is effective in helping EFL learners/writers to improve the accuracy of their writing. Also it can be concluded that Iranian English learners do prefer to receive written corrective feedback on their writing in order to identify their errors and mistakes. Furthermore feedback helps them improve their writing accuracy. At the same time, the analysis of the data shows that different types of corrective feedback have apparently varying effects on the students' writing accuracy. By considering grammatical writing accuracy, it can be concluded that metalinguistic corrective feedback was more effective on the learners' performance.

This study set out to continue the line of FL study attempting to gain a better understanding of the role of written corrective feedback in foreign language writing pedagogy. It provided an overview of written corrective feedback as one of the major issues in the domain of error correction in writing. It elucidated two types of corrective feedback, reviewed and recapitulated the theoretical and experimental surveys about written corrective feedback in order to show the central role it has on triggering students to be aware of the gap that exist between their non-target like speech and the target forms.

\section{References}

Allwright, R. (1975). Problems in the study of language teacher's treatment of error. In M. Burt \& H. Dulay (Eds.), New directions in second-language learning, teaching and bilingual education (pp. 96-109). Washington: DC.

Asiri, I. (1996). University EFL Teachers' Written Feedback on Compositions and Students' Reactions. Unpublished doctoral dissertation. University of Essex.

Bitchener, J. (2008). Evidence in support of written corrective feedback. Journal of Second Language Writing, 17, 102-118. http://dx.doi.org/10.1016/j.jslw.2007.11.004

Brooks, N. (1960). Language and language learning. Theory and practice. New York: Harcourt, Brace \& World.

Brown, D. H. (2007). Principles of language learning and teaching (5th ed.). NY: Pearson Educations, Inc.

Butler, D. L. (1988). Enhancing and undermining intrinsic motivation: The effects of taskinvolving and ego-involving evaluation on interest and involvement. British Journal of Educational Psychology, 58, 1-14. http://dx.doi.org/10.1111/j.2044-8279.1988.tb00874.x

Chandler, J. (2003). The efficacy of various kinds of error feedback for improvement in the accuracy and fluency of L2 student writing. Journal of Second Language Writing, 12, 267-296. http://dx.doi.org/10.1016/S1060-3743(03)00038-9

Corpuz, V. A. F. (2011). Error correction in second language writing: Teachers' beliefs, practices, and students' preferences. Unpublished masteral thesis. Queensland university technology factually of education. 
Elashri, I. I. E. A. F. (2013). The Impact of the direct teacher feedback strategy on the EFL secondary stage students' writing performance. Unpublished doctoral dissertation. Mansoura University.

Ellis, R. (2009). A Typology of written corrective feedback types. ELT Journal, 63(2), 97-107. http://dx.doi.org/10.1093/elt/ccn023

Ellis, R., Sheen, Y., Murakami, M., \& Takashima, H. (2008). The effects of focused and unfocused written corrective feedback in an English as a foreign language context. System, 36, 353-371. http://dx.doi.org/10.1016/j.system.2008.02.001

Ferris, D. R. (1999). The case for grammar correction in L2 writing classes: A response to Truscott (1996). Journal of Second Language Writing, 8, 1-11. http://dx.doi.org/10.1016/S1060-3743(99)80110-6

Goldstein, L. (2004). Questions and answers about teacher written commentary and student revisions: Teachers and students working together. Journal of Second Language Writing, 13, 63-80. http://dx.doi.org/10.1016/j.jslw.2004.04.006

Guénette, D. (2007). Is feedback pedagogical correct? Research design issues in studies of feedback on writing. Journal of Second Language Writing, 16, 40-53. http://dx.doi.org/10.1016/j.jslw.2007.01.001

Hino, J. (2006). Linguistic information supplied by negative feedback: A study of its contribution to the process of second language acquisition. Unpublished doctoral dissertation. University of Pennsylvania.

Littleton, Ch. (2011). The Role of feedback in Two Fan fiction writing Groups. Unpublished doctoral dissertation. Indiana University of Pennsylvania.

Lyster, R. (2007). Learning and teaching languages through content: A counter balanced approach. Amsterdam: Benjamins. http://dx.doi.org/10.1075/11lt.18

Rashidi, N., \& Babaie, H. (2013). Elicitation, recast, and meta-linguistic feedback in form-focused exchanges: Effects of feedback modality on multimedia grammar instruction. Journal of Teaching Language Skills, 4(4), 25-51.

Schmidt, R. (2001). Attention. In P. Robinson (Ed.), Cognition and second language instruction (pp. 3-32). Cambridge: Cambridge University Press. http://dx.doi.org/10.1017/CBO9781139524780.003

Schmidt, R. (1993). Interaction, acculturation and the acquisition of communicative competence. N. Wolfson \& E. Judd (Eds.), Sociolinguistics and language acquisition (pp. 137-174). Rowley, MA: Newbury House. http://dx.doi.org/10.1017/cbo9781139524780.003

Shahivand, Z., \& Pazhakh, A. (2012). The effects of test facets on the construct validity of the tests in iranian EFL students. Higher Education of Social Science, 2(1), 16-20. 


\section{Macrothink}

Journal of Studies in Education

ISSN 2162-6952 2016, Vol. 6, No. 2

Sheen, Y. (2007). The effect of focused written corrective feedback and language aptitude on ESL learners' acquisition of articles. TESOL Quarterly, 41, 255-283. http://dx.doi.org/10.1002/j.1545-7249.2007.tb00059.x

Truscott, J. (1996). The case against grammar correction in L2 writing classes. Language Learning, 46, 327-369. http://dx.doi.org/10.1111/j.1467-1770.1996.tb01238.x

Truscott, J. (1999). What's wrong with oral grammar correction. Canadian Modern Language Review, 55, 437-456. http://dx.doi.org/10.3138/cmlr.55.4.437

Truscott, J., \& Hsu, A.Y. (2008). Error correction, revision, and learning. Journal of Second Language Writing, 17, 292-305. http://dx.doi.org/10.1016/j.jslw.2008.05.003

VanPatten, B. (2003). From input to output: A teacher's guide to second language acquisition. Mahwah, MJ: Erlbaum. 